\title{
DAYACLIM: A northern Sahara desert climate change project
}

Belhadj Hamdi-Aïssa ${ }^{1,2}$ and Nacer Messen ${ }^{2}$

${ }^{1}$ Dép. Sci. Agronomiques, Laboratoire de Biogéochimie des Milieux Désertiques and ECO-SYS, Université de Ouargla, Algeria; hamdi_30@yahoo.fr

${ }^{2}$ Centre de Recherche Scientifique et Technique sur les Région Arides, Biskra, Algeria; n_messen@hotmail.com

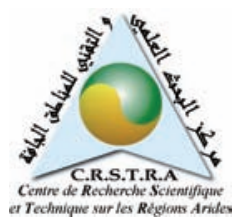

In order to address the consequences of global change in the Northern Sahara Desert (NSD) region, an initiative for collaborative research on global change in this region, the DAYACLIM project (N¹7/03/01/02/ MN), was officially launched in February 2003. This initiative formulates and coordinates an integrated multidisciplinary approach to observing, reconstructing, and modeling global change phenomena and processes in the NSD region.

\section{Objectives}

The DAYACLIM objectives are:

- Understanding past climate changes and variability to improve the prediction of future global environments

- Contributing to the understanding of the origin and causes of climate changes and variability, and collecting archived information useful for paleoclimatic reconstruction of the NSD region

- Understanding the interaction between groundwater and hydrological changes.

- Establishing a database for paleoenvironmental data from the NSD region

- Providing a coordinated contribution of Algerian research to multidisciplinary international projects, and exploring the possibilities of future paleoenvironmental research.

\section{Strategy}

DAYACLIM paleoclimatologists have two major concerns: (i) to select sites for investigation with high-resolution signals of climate changes and variability; (ii) to make sure that these investigated sites offer continuous signals of past climate oscillations.

Flooded base-level plains and endorheic (closed) depressions where water is periodically stored at the surface could function as paleoclimate geo-archives of hydrological changes during interglacial phases in the NSD region (Rognon, 1980; Messen

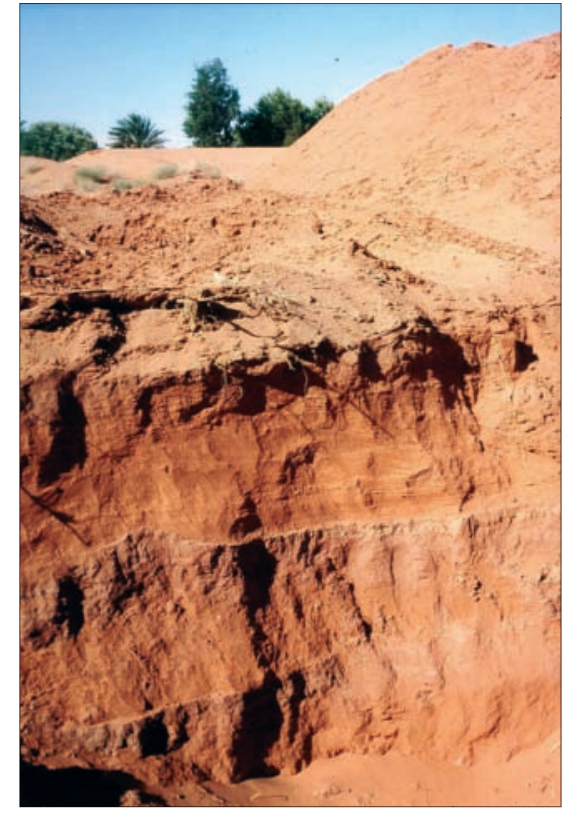

Figure 1: Pedo-sediment layers in the investigated area.

et al., 2004). Sediments in depressions fall dry temporarily during arid phases and get covered with a sand layer and eolian sand deposits (Fig. 1). Thereafter, the fluvial and detritic sediments transported by water during pluvial phases are interstratified with sandy accumulations.

Our approach relies on the theory of biorhexistasy, which describes a complex succession of sedimentation/pedological phases alternating with erosional episodes, both being controlled by climate forcing (Fedoroff and Courty, 1999). The concept of hierarchy of soil attributes (i.e. paleosol) in terms of a chronology of events and their paleoclimatic significance (Fedoroff and Courty, 1999, Hamdi-Aïssa, 2002) is adopted in the DAYACLIM project.

For dating the pedo-sediment layers, we will have recourse to absolute and relative dating. According to the time interval and the nature of the selected material, useful chronostratigraphic methods are limited to:

1. Uranium series absolute dating

2. Electronic Spin Resonance (RSE)

or Electronic Paramagnetic

Resonance (RPE)
3. Optically Stimulated Luminescence induced by laser (OSL) A particular stratigraphic challenge for dating is to quantify hiatuses, i.e. to evaluate the duration corresponding to the absence of deposits, which usually occur at the transitions from arid to humid periods and inversely.

The 1st interdisciplinary DAYACLIM Workshop "Dating of climate oscillations, hydrologic and thermic events in North Africa", was sponsored by the EUR-OPA Risques-Majeurs and organized by CRSTRA and Ouargla University, Algeria, from 3-4 March 2004, followed by a fieldtrip to the DAYACLIM investigation field site.

The DAYACLIM research group welcomes international scientific or financial collaboration.

Notes

DAYACLIM is named for "Dayas" (Daïas), a North African and Middle Eastern word meaning desert non-saline endorheic depressions on limestone areas.

\section{ACKNOWLEDGements}

DAYACLIM is formally endorsed by the Arid Regions Research Centre (CRSTRA) (Prof. A. Gaouar, N. Ferhat), Ouargla University (Prof. B. Hamdi-Aïssa, M. Hacini, B. Djili, F. Youcef), Tebessa University (Prof. A. Djerrab), USTHB University (Prof. F. YoucefEttoum, S. Benzinah) and Algerian Nuclear Research Centre (CNRB-CNRA) (Prof. N. Messen, D. Imatoukéne), INA Alger ( $H$. Aouam).

\section{REFERENCES}

Fedoroff, N. and Courty, M.A., 1999: Soil and soil forming processes under increasing aridity. In: Singhvi, A.K., and Derbyshire, E. (Eds). Paleoenvironmental reconstruction in arid lands. Oxford \& IBH, New Delhi, 73-108.

Hamdi-Aïssa, B. 2002: Paleogeochemical interpretation of some gypsic microfabrics in hyper-desert soils. In: ISSS ed, 17th World Congress of Soil Science, Bangkok, (CD-Rom publication), paper $\mathrm{n}^{\circ}$ 1861:1-9.

Messen, N., Gaouar, A., Hamdi-Aïssa, B., Hacini, M. and Youcef-Ettoumi, F., 2004: Etude du climat paléolithique dans un bassin sédimentaire du sud algérien: sélection du site. Journal Algerien pour les Zones Arides, 3: 38-44.

Rognon, P., 1980: Pluvial and arid phases in the Sahara: the role of non climatic factors. In: Sarnthein, M., Seibold, E. and Rognon, P., (Eds.), "Sahara and Surrounding Seas", Palaeoecology of Africa, 12: 45-61. 